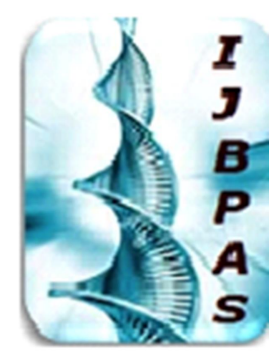

International Journal of Biology, Pharmacy

and Allied Sciences (IJBPAS)

'A B Bridge Betuben Caboratory and QRade'

Www.jibpas.com

\title{
LEGAL, ECONOMIC AND MANAGERIAL ASPECT OF SOLID WASTE MANAGEMENT
}

\section{GUPTA P}

Assistant professor, Madhav Vidhi Mahavidyalaya Gwalior

"Corresponding Author: Dr. Pooja Gupta

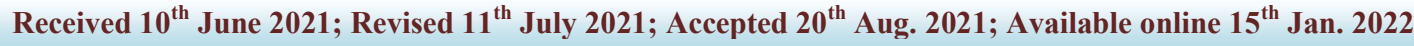

https://doi.org/10.31032/IJBPAS/2022/11.1.1081

ABSTRACT

The directive ideas of nation policy (Article 47) in Indian constitution ask for the safety of surroundings through the country first of the ministry of surroundings and forests make rules for the regulation of waste. As the Environment Protection law 1990 states," waste is described as any substance which represent a robust material, or a power or different undesirable surplus substance springing up from Asian of any process. Where strong waste is essentially a strong or semi strong home waste, it can be any home sanitary institutional waste etc. With speedy urbanization, industrialization and an explosion off populace in India, waste control can be a key task for kingdom authorities and neighbourhood municipal our bodies in twenty first century ${ }^{1}$.

"Swachh Bharat Abhiyan" "clean India" task turned into began out on October $2^{\text {nd }}$ of year 2014 to cope with problems associated with waste control, cleanliness and sanitation on our countrywide degree most effective $68 \%$ of the rubbish generated withinside the united states is accrued apparent $28 \%$ is dealt with the aid of using municipal government untapped waste can generate extra than 30,000 of TPT of flamable waste first of the quantity of approaches this is generated, if accumulated and handled well, may be successfully used to create energy. WHO says that twenty kinds of illnesses may be averted or managed through enhancing stable waste control in India, as a result the informal mind-set in the direction of waste control have to change.

\section{Keywords: Solid Waste Management, Legal Aspects, Economic Aspects}

${ }^{1}$ Vaishali Anand Kumar environmental law $3^{\text {rd }}$ edition 2019 


\section{INTRODUCTION}

Waste is a material which constitute a robust cloth or and effluent or special unwanted supply substance bobbing up from Application of any process. With speedy urbanization and distillation and explosion of population in India, waste manage grow to be a venture for governments and close by our bodies the ones days. Waste is generally of undersigned types $^{2}$ :-

1. Decomposable waste:- They degraded through microbial interest for prevent the precept examples are food residue and human excreta .

2. Non Decomposable waste:- They do now not degrade. The number one examples are petroleum, plastic, glasses etc.

3. Biomedical waste:- Usually, the leftovers from medicine, along with needle alternate arrange, body parts, are counted as biomedical waste.

4. E-waste laptop parts, battery is exchange CFL bulbs are some of the precept examples.

5. Solid waste sturdy waste is basically a robust or semi solid domestic waste, sanitary waste, enterprise waste, institutional waste etc. It is also referred to as municipal sturdy waste.

${ }^{2}$ Manual on municipal solid waste management
In specific words municipal solid waste is embody own circle of relatives trash garbage, rubbish, manufacturing based, manufacturing residues and packaging materials trade refugees etc, are managed thru municipalities.

Government of India had notified the municipal robust waste manipulate And coping with tips in $2000^{3}$, there with the useful resource of the use of making it compulsory for all town close by our bodies withinside America of a to have interaction in collection segregation, secondary storage in blanketed bins, transportation in protected vehicles, processing through composting or techniques to strength generation and disposal of rejects in engineered, sanitary landfills. Some of the primary troubles concerning solid waste manage are as follows :-

- Absence of saturation of waste at source

- $\quad$ Lack of financing

- Lack of technical facts and appropriate instructional arrangement

- $\quad$ Lack of willingness.

- Solid waste control

This isn't the appealing in India because of

\footnotetext{
${ }^{3}$ Vaishali Anand Kumar environmental law $3^{\text {rd }}$ edition 2019
} 
excessive moisture and natural content material and coffee calorific fee of the waste first of the Lucknow bio methane country plant in 1990 failed as it turned into designed to deal with best as soon as aggregated waste however needed to deal with combined scrap. There is a want to offer suitable incentives and regulatory framework wishes to be provided. There are different schemes as nicely to cope with stable waste and they may be mentioned below.

1. Incineration :- Incineration Process can lessen the authentic extent of combustors strong waste through eighty to $90 \%$

- Incineration entails the combustion of natural substance containing waste substances

- Incineration may be defined as thermal remedy

- Incineration of waste cloth converts the waste into ash, flue fueloline and warmth.

2. Prolysis :- Here the stable is transformed into liquid kingdom and liquid is transformed into fuel line first of those merchandise of remedy can be used for after for the manufacturing of strength.

3. Methanogenesisor :- It is Biomethanation process, this is process for formation of methane via way of means of microbes called methane's. The essential goal is to supply an advanced stable gasoline or pilots from strong waste.

4. Recycling :- for every recyclable and reusable materials

5. Sensitisation :- off citizen in addition to authorities authorities, network participation, involvement of citizen in addition to authorities authorities, network participation, involvement of NGOs . littering must be prohibited, littering have to be prohibited.

\section{Segregation and network participation ${ }^{4}$} are the important thing factors. Plastic luggage were banned in some of large towns.

Waste control may be performed in methods

- Waste discount and

- Recycling

Government Planning Commission highlights the want for an included technique, meaning five $R^{\prime} \mathbf{s}^{5}$

- Reduce

- $\quad$ Reuse

- Recover

\footnotetext{
${ }^{4}$ Vaishali Anand Kumar environmental law $3^{\text {rd }}$ edition 2019

${ }^{5}$ Environment Protection Act 2000
} 
- Recycle and

- Remanufacture

It emphasize is putting in place of processes for waste control. One of that's centralised technique for incineration, gasification, prolysis.and the second is decentralised for biomethanation \& vermicomposting.

Legal Aspects of strong waste control : ${ }^{6}$ Solid waste turned into brazenly criticised with the aid of using global Commission on surroundings and improvement withinside the record in year 1987. In India there are numerous legal guidelines concerning strong waste control and to adjust the system of strong waste control, as follows :-

Municipal stable waste control and dealing with guidelines 2000

It is relevant on each municipal branch who works for the gathering of strong waste this act changed into in addition changed with the aid of using strong waste control guidelines in year 2016. This act prolonged the operating location and paintings of municipal branch in regards to the municipal waste, this act isn't best relevant on nearby our bodies it additionally relevant on each public area and historic vicinity and government. This act brought the time period waste generator

${ }^{6}$ Vaishali Anand Kumar environmental law $3^{\text {rd }}$ edition 2019 additionally.

But the simplest problem of this act is that it's miles best for Solid waste there's no provision for different dangerous waste $\mathrm{y}$ wastes and different special varieties of waste.

There are separate provisions for risky waste, E-Waste and different waste stated in Environment Protection act 1986. There are a few penal provisions also are noted in chapter 14 of Indian Penal Code 1860 and additionally in section 133 of criminal system code 1973.

\section{Indian Penal Code 1860}

Chapter 14 of Indian Penal Code 1860 said provisions concerning the offences affecting the general public fitness, safety, convenience, decency and morals. Section 269 of the code, said the provisions concerning the negligent act possibly to unfold contamination of disorder risky to lifestyles According to this segment whoever unlawfully and negligently it does any act which is, and which he is aware of or has purpose to trust to be calmer probable to unfold the contamination of any ailment risky to existence industrial be punished with imprisonment for both description for a time period which may also make bigger it to six month, or with excellent, or with each for

\footnotetext{
${ }^{7}$ Indian penal code 1860 , bare act
} 
prevent the workplace beneath this segment is cognizable bailable remark non compoundable and tribal through any magistrate. The cause at the back of this phase is to punish the polluter or the person that unfold waste and additionally the government who didn't satisfy their obligation to dispose and accumulate the waste on right time which bring about spreading contamination of illnesses risky to lifestyles.

Similarly section 270, of the code said provisions concerning malignant actor probably to unfold contamination of disorder risky to existence wherein the wrongdoer will be punished with imprisonment of both description for a time period which may also increase to 2 years or with first-class or with each.

\section{Economic Aspects of Waste Management}

Solid Waste Management is part of public fitness of country and in line with the Indian ls in the horizon of the nation list. Since this exertion is nonexclusive, unexampled. \& vital the duty for furnishing the offerings lies inside public sphere. The exertion being of unique nature is entrusted to the outside government. Public interest to stable waste and recycling has accelerated dramatically over the as soon as decade. To perform this important exertion an periodic provision for the recreating and capital expenditure is made withinside the outside price range. The outside price range is grounded on the full earnings from Central and State Government. The provision of budget for strong waste operation is typically determined to be made on adhoc base and isn't associated with the demand. Solid Waste Management gets a relatively shy percentage out of the combination outside price range because the outside businesses assign low priority to this paintings acting in negative offerings. The stable Waste Management conditioning could be ruled through the morals of Public Finance - Videlicet the Principles of Maximum Social Advantage. In precept the weight of obligation for backing Solid Waste Management have to fall the least at the decrease profits companies and precipitously at the centre and superior profits classes. It doesn't wanted a defence in phrases of "fantastic returns on funding" gains". An funding nevertheless wishes to be justified at the grounds of being "the least fee technologically attainable option" for reaching the wished diploma of effectiveness. Economists have evolved fashions to assist coverage makers pick out the powerful combo of coverage situations to adjust Solid Waste \& recycling. Economists

\footnotetext{
${ }^{8}$ Manual on municipal solid waste management
} 
have additionally hired special varieties of information to estimate the elements that make contributions to the technology of Solid Waste, recycling and to estimate the effectiveness of several of the coverage alternatives hired. Economists have additionally expected the connection among schooling and ménage scrap summations. Educated houses can be more worried of recuperating openings. It turned into plant that boom withinside the length of family decreases the consistent with-capita quantity of scrap disposed. Proper waste control will bring about generate finance additionally as biodegradable waste and different waste are useful in producing electricity making cement and numerous different things, wherein stable family waste is beneficial in making fertilizers etc. The $10 \%$ of quantity allocated to the municipal branch for waste series is spend over the weekend and the humans had for the gathering of the waste from door to door which may be re earned through right control and usage of waste. Five R's are the fundamental line and the essential unit to recreate the price range from the waste that could assist in financial system manner very effectively.

\section{CONCLUSION}

With better boom in populace the hassle of waste is likewise growing in step with day strong family waste series is the essential paintings of municipal government because it consists of series, disposal and different sports additionally in conjunction with the control of strong waste. As after the strong waste control guidelines 2016 got here up the quantity of strong waste series isn't always restrained best to municipal government it prolonged to each public location and public private as obligation of each citizen. The indifference of citizens, loss of network participation and CVS control plan are vital problems first forestall Kasturrangan document through erstwhile Planning Commission highlights the want open included method meaning the five hours concept. There is a complete criminal and regulatory framework in area in India to cope with such problems, which encompass a loss of economic resources, scarcity of staff, loss of preferred protocols and a loss of felony authority.

\section{REFERENCES}

[1] www.studymode.com

[2] Environment Protection Act 2000

[3] Environment Protection rules2016

[4] KVS Madaan, paper 1 UGC Net $4^{\text {th }}$ Edition

[5] SC Tripathi, environmental law $17^{\text {th }}$ edition 2019 
[6] Vaishali Anand Kumar environmental law $3^{\text {rd }}$ edition 2019

[7] Manual on municipal solid waste management

[8] Manjusha. N. Sarnobat economic aspect of solid waste management 